BOGUSEAW ŚLIWERSKI

Uniwersytet Łódzki

\title{
POSTFUTBOLOWA PEDAGOGIKA I JEJ APLIKACJE W ANALIZIE EDUKACYJNYCH ZJAWISK
}

\begin{abstract}
AвSTRACt. Śliwerski Bogusław, Postfutbolowa pedagogika i jej aplikacje w analizie edukacyjnych zjawisk [Post-Football Pedagogy and Its Applications in the Analysis of Educational Aspects]. Studia Edukacyjne nr 44, 2017, Poznań 2017, pp. 7-22. Adam Mickiewicz University Press. ISSN 1233-6688. DOI: $10.14746 /$ se.2017.44.1
\end{abstract}

For the author of the text, football is not only a reference to the most recent publications in education sociology and cultural anthropology on this sport in the lives of postmodern societies, but also a metaphor for an analysis of selected issues of the educational policy and higher educations in Poland.

Key words: football, soccer, post-football, fanaticism of football fans, pop culture, pedagogics, education, glottodidactics, school final exam

\section{Wprowadzenie}

W 2012 roku ukazała się na naszym rynku książka o postfutbolu. Do druku przygotowali ją: antropolog kultury Mariusz Czubaj wraz z doktorantem Jackiem Drozdą i trenerem oraz analitykiem piłkarskim Jakubem Myszkorowskim ${ }^{1}$. Wprowadzenia dokonał niekwestionowany autorytet naukowy w tej dyscyplinie Wojciech J. Burszta, dla którego tekst książki stał się dodatkową okazją do wspomnień i nostalgicznych ewokacji z czasów, kiedy sam był uczestnikiem boiskowej communitas. Nic dziwnego, że najchętniej sam opowiadałby o tym w nieskończoność. A jednak, to nie on dokonuje tej narracji, tylko przedstawiciele trzech pokoleń połączonych wspólną pasją odczytywania kulturowych znaczeń, jakie wpisują się w świat piłki nożnej od

${ }^{1}$ M. Czubaj, J. Myszkorowski i in., Postfutbol. Antropologia piłki nożnej, Gdańsk 2012. 
czasów jej powstania i rozwoju w perspektywie kultu amatora, poprzez jej paleotechniczny raj, aż po ponowoczesny futbol, czyli postfutbol.

Książka wciąga nie tylko fascynującą narracją, analizą zjawisk, które dotychczas przeciętnemu (w sensie statystycznym) kibicowi nawet nie przychodziły na myśl, ale i odsłoną kulis piłki nożnej wraz z towarzyszącą jej oprawą. Mimo że dla każdego chłopca piłka nożna jest tylko grą, którą feministki usiłowały zdewaluować jeszcze przed Euro 2012, że ich zdaniem bieganie 22 spoconych mężczyzn za czymś okrągłym przyczyni się jedynie do zwiększenia procederu prostytucji, to jednak antropolodzy kultury pokazują to, co dla nas jest niewidoczne. Piszą o tym, co tworzy zupełnie nowe wymiary kultury w naszym codziennym życiu prywatnym, społecznym i zawodowym. Ich agresja chyba jeszcze bardziej wzrośnie po lekturze tej książki, bowiem jej autorzy piszą także o tym, dlaczego piłka nożna ma płeć kulturową, czyli o powodach i mitach stwarzających bariery dla kobiet w tym sporcie. Zwolennicy lewicowych ruchów społecznych dowiedzą się przy tej okazji, kto był pierwszym powszechnie znanym gejem wśród piłkarzy mimo jakże typowego przekonania, że jest to dyscyplina hetero-, machoi metrocentryczna.

Genialny pomysł badawczy został zrealizowany w niezwykle subtelny, jak dla naukowców sposób, bowiem tę książkę może przeczytać każdy, kto w ogóle nie studiował ani humanistyki, ani nauk społecznych, czy tym bardziej nauk o kulturze fizycznej. To jest publikacja napisana językiem naukowym, ale w taki sposób, by nie zrazić do przekazywanych treści każdego miłośnika sportu. Tak więc i akademicy znajdą w niej fundamentalne dla science odniesienia do źródeł i liderów światowej wiedzy o tym sporcie zespołowym, podobnie jak jego komentatorzy, animatorzy, czy kibice. Polacy, nic się nie stało! Sromotnie przegraliśmy Euro 2012, ale za to, ile zyskaliśmy przy tej okazji - przejezdne autostrady, nową infrastrukturę sportowo-turystyczną, nieco zmodernizowane koleje i lotniska, no i odzyskaliśmy na czas tych „igrzysk” wspólnotę narodową, patriotyczną, które tak bardzo potrzebne są każdemu narodowi, każdej wspólnocie w czasach kryzysów, podziałów i konfliktów.

Nic tak bardzo nie jednoczy ludzi, jak własna drużyna walcząca w ich imieniu o godność zwycięzcy. A Polacy zwyciężyli już przed Euro 2012, skoro pojawiły się także w świecie nauki projekty opisania tego, z czego nie wszyscy zdają sobie sprawę. Sam mam coraz więcej studentów, którzy w mijającym roku akademickim zgłaszali chęć napisania prac dyplomowych o aktywności wychowawczej czy samowychowawczej młodzieży w ramach pasjonującej ich dyscypliny sportowej. Być może zatem właśnie dzięki Euro 2012 mamy książkę o postfutbolu! Warto sięgnąć po ten antropologiczno-kulturowy „kryminał”, bo w istocie zaczyna się on od niezwykle intrygującego zdania: 
(...) dzieje piłki nożnej nie rozstrzygają się na boisku podczas finałowego meczu o mistrzostwo świata lub kontynentu, ale w zaciszach gabinetów i przy negocjacyjnych stołach ${ }^{2}$.

Dzięki temu studium dowiadujemy się o związkach postfutbolu z technopolizacją i cyborgizacją futbolowych doświadczeń, koneksjami dokonującymi się między piłką a obszarami ekonomii, polityki, marketingu, reklamy i sportowego wizerunku, przemysłu, neotelewizją, a zarazem konserwatywną postawą władz FIFA i UEFA wobec propozycji wykorzystania nowych technologii do rozstrzygania o kontrowersyjnych golach, faulach, rzutach rożnych itp. Wytrawni poszukiwacze nowych metafor i teoretycznych podejść w badaniach podstawowych w humanistyce znajdą tu odniesienia socjokulturowe do postrzegania piłki nożnej jako sportu okrucieństwa, przemocy, panoptykonu, sprytu i przebiegłości nie tylko zawodników, przestrzeni dla karnawalizacji, ale i mistyfikacji, dynamicznego rozwoju edukacji, demokratyzacji lub szlachetnego elitaryzmu.

Przywołana tu narracja futbolowa Władimira Proppa z jego schematem „konstruowania przez kibiców przegranej drużyny bajki magicznej”, by podtrzymać legendę o szczególnej mocy własnej drużyny, pozwoli nam znieść gorycz porażki sprzed kilku dni. A może komuś spodoba się odpowiedź Kupera i Szymanskiego na pytanie, które nie mogło mieć przecież w czasie jej powstania związku z wynikiem meczu Polska-Czechy,

dlaczego ten model budowania tożsamości - w oparciu o poczucie, że zwycięstwo się należy, ale nie jest ono możliwe wskutek nagromadzonej złej woli wokół nas - jest tak żywotny ${ }^{3}$.

Antropolodzy ujawniają także kulturowe kulisy nie tylko stadionu, ale i przestrzeni szatni w przerwie między rozgrywanymi połowami meczu. Autorzy książki wyjaśniają przyczyny, dla których piłka nożna ma angielskie korzenie, ale francuską jakość. Zrozumiemy dzięki temu, dlaczego Brytyjczycy, tak jak Polacy, nie potrafią uczyć się na własnych błędach, w związku z czym to inni zbierają laury za ich innowacyjność. Są w tej książce także Polonica demistyfikujące powody, dla których władza ludowa okresu PRL w brutalny sposób zmieniła semantykę ligi piłkarskiej, proletaryzując nazwy klubów piłkarskich o tradycjach niepodległościowych oraz dlaczego kardynał Karol Wojtyła mógłby nie zostać wybrany papieżem, gdyby w 1978 roku polska drużyna pokonała w finale Niemców. Wątek „,co by było, gdyby” bardzo mnie ucieszył, bo dzięki niemu okazuje się, że antropologia kulturowa jest na tym samym poziomie naukowości co pedagogika.

\footnotetext{
${ }^{2}$ Tamże, s. 15.

${ }^{3}$ Tamże, s. 50.
} 
Treść tej lektury znakomicie koresponduje z rozprawami Zbyszko Melosika na temat roli i miejsca popkultury oraz ciała, cielesności i władzy w ponowoczesnych społeczeństwach ${ }^{4}$. Sam zastanawiałem się, czy włókna mięśniowe w mięśniach moich nóg są szybkokurczliwe czy wolnokurczliwe, a tym samym czy mam jeszcze szansę zaistnieć w piłce nożnej już jako kibic. Wszechobecność ciała kibicowskiego miesza się w tej rozprawie z oralnością piłkarskiego spektaklu i sportowego przemysłu, stadionowa nagość z ujarzmianiem przez władze kibolizmu w "strefach kibica”. Ucieszyła mnie przy tym konstatacja naukowców, że ciało kibica jest podmiotowe, a ciało piłkarza utowarowione, choć zarazem pozbawione potencjału ułomności. Zrozumiałem także, jaka jest różnica między dziesiątkami tysięcy graczy potrafiących wykonać każdy element techniczny w komfortowych warunkach w porównaniu z piłkarzem naszej reprezentacji - Robertem Lewandowskim, który $\mathrm{w}$ czasie mistrzostw, osamotniony $\mathrm{w}$ ataku pozycyjnym, mógł korzystać $\mathrm{z}$ tych umiejętności w warunkach ostrej rywalizacji.

Antropokulturowa opowieść o piłce nożnej, wbrew przedmiotowi swoich dociekań, nie jest dziełem zamkniętym, z introdukcją, rozwinięciem i kodą, gdyż dopiero teraz można ją rozwijać na wszystkie z możliwych w naukach społecznych sposoby. Także specjaliści od dziennikarstwa, komunikacji społecznej i mediów dowiedzą się o regułach mówienia i pisania o piłce nożnej w świecie, jej herosach i postaciach tragicznych, wynoszonych pod niebiosa i wykluczanych z własnych drużyn przez jej kibiców. Świat piłki nożnej, który tak bardzo zmienił się z romantycznej i bezinteresownej rywalizacji w swoistego rodzaju przemysł, często pozbawiony etycznych zasad, jest zbieżny z tym, co dzieje się w polskim szkolnictwie powszechnym i wyższym.

\section{Komparatystyka wobec piłki nożnej}

Najnowsza książka Zbyszko Melosika o piłce nożnej niewątpliwie trafi pod strzechy nauk pedagogicznych ${ }^{5}$. W socjopedagogicznej monografii naukowej poznańskiego pedagoga ma miejsce, we wprowadzeniu, odsłona jego zamiłowania do tej dyscypliny sportu. Dzięki temu naświetla jej kulturowe konteksty w zglobalizowanym świecie wartości i ludzkich pasji. Nie jest istotne to, co sądzili na temat piłki nożnej klasycy współczesnej humanistyki, czy nauk społecznych, politycy, czy nawet krytycy literatury i mediów. Jak pisze:

Niezależnie zresztą od krytyki piłka nożna jest bez wątpienia jedną z najbardziej globalnych (i powszechnie akceptowanych) praktyk kulturowych, urzeczywistnianych

\footnotetext{
${ }^{4}$ Z. Melosik, Tożsamość, ciało i władza w kulturze instant, Kraków 2010.

${ }^{5}$ Z. Melosik, Piłka nożna. Tożsamość, kultura i władza, Poznań 2017.
} 
na stadionach całego świata, w niekiedy bardzo skomplikowanych procesach readaptacji ${ }^{6}$.

Na przeczytanie tej pasjonującej książki niektórym wystarczy znormalizowany czas trwania meczu piłkarskiego, a więc $2 \times 45$ minut. Jak ktoś chce dostrzec głębsze walory analiz tego znakomitego w Polsce komparatysty, to skorzysta nie tylko z przysługującej w wyniku remisu czasu na "dogrywkę" $(2 \times 15$ minut), ale może uruchomić jeszcze cykl spotkań i debat naukowych w ramach naukowej ekstraklasy, odbywając je regularnie co tydzień lub raz na cztery lata. Książkę bowiem czyta się szybko, z ogromną przyjemnością, której doświadczą także kobiety, bowiem znajduje się w niej rozdział o piłce nożnej „słabej, ale za to pięknej płci”. Tak więc publikacja jest zrównoważona genderowo. Sam sięgnąłem po nią z osobistą pasją, bo doskonale pamiętam tysiące godzin spędzonych na podwórku z piłką nożną i kolegami z okolicznych bloków, skąd byliśmy regularnie przeganiani przez mieszkańców w emerytalnym wieku, którzy nie mogli znieść towarzyszących grze emocji, okrzyków, a czasami i niecenzuralnych słów niektórych kibiców. Podejście Z. Melosika do sportowej rywalizacji piłkarskiej tylko pozornie wyklucza autobiograficzną refleksję u tych czytelników, którzy nie mieli nic wspólnego z zawodowym czy amatorskim sposobem jej uprawiania pod kierunkiem trenerów i specjalistycznych ekip. Pozwala zarazem dostrzec, jak piłka nożna staje się - w świetle teorii M. Foucaulta - środowiskiem kształtowania się tożsamości narodowej, kulturowej, a nawet ideologicznej w społeczeństwach dotkniętych futbolowym szałem. To w tej praktyce społecznej, a nie tylko cielesnej, fizycznej, odbywa się złożony i niewidoczny dla większości proces kulturowej socjalizacji - readaptacji, rekonwersji kulturowej, ruchliwości społecznej i stratyfikacji ekonomicznej, inkulturacji w skali mikro (intra- i interpersonalnej), mezo- (instytucjonalnej) oraz makro (globalnej).

Zbyszko Melosika interesuje geneza rodzenia się i utrwalania tych procesów oraz ich kulturowych zmian w toku dziejów i na wybranych kontynentach świata czy krajach. Dzięki temu widzimy przemieszczanie się w czasie i przestrzeni wzajemnie sprzecznych zjawisk: elitaryzm/arystokratyzm $v s$ proletaryzacja piłki nożnej; swojskie vs obce; lokalne vs ponadlokalne; krajowe $v s$ zagraniczne; nacjonalistyczne $v s$ uniwersalistyczne; patriotyczne $v s$ kosmopolitycznie nacjonalistyczne; kontynentalne vs światowe; sprywatyzowane vs upaństwowione; osobiste vs zinstytucjonalizowane; klasowe vs wieloklasowe; rasowe vs wielorasowe; otwarte vs niedostępne; indywidualizm vs kolektywizm; egocentryzm vs prospołeczność; lojalność vs zdrada; profesjonalizm vs improwizacja; rywalizacja vs współpraca; moralność vs demoralizacja; peryferyjność vs mocarstwowość.

\footnotetext{
${ }^{6}$ Tamże, s. 11.
} 
Nareszcie widzimy niezwykle ważną edukacyjnie rolę klubowej piłki nożnej w alfabetyzacji dzieci i młodzieży ze środowisk wykluczenia społecznego. Ta gra staje się teatrem nie tylko aktorów, ale i widzów, scenografów, autorów scenariuszy. To także wielki biznes i wydawałoby się nieracjonalne, a horrendalne zyski dla najlepszych, czy polityka służąca demokratyzacji lub utrzymaniu reżimu, a wszystko razem staje się szansą do budowania poczucia tożsamości narodowej i własnej wartości. Możemy przenieść sztukę piłkarskich zwycięstw na taktyki, z jakimi spotykamy się, czy których osobiście doświadczamy w naszych środowiskach zawodowych lub społecznych, a więc triki, fortele, zwody, dryblingi, przebiegłość, faule, wyrafinowanie, bezwzględność, nienawiść, rebelię, umiłowanie podstępu ("gra faulem jest nieporównywalnie bardziej satysfakcjonująca niż gra fair"7), czy zręczność, pomysłowość, błyskotliwość, kreatywność, spontaniczność, wirtuozerię, ofensywność, obronność, celebrytyzm, paternalizm, wykorzystywanie cech fizycznych (ciało, uroda, wytrzymałość, sprawność, męskość, seksualizm, zwyczaje żywieniowe itp.).

Fani futbolu znajdą w tej książce coś dla siebie, o ile reprezentują środowisko intelektualnie zdolne do czytania czegoś więcej, niż tylko wyniki meczów czy rankingi najlepszych piłkarzy. Nie każdy może skorzystać w pełni z tego „laboratorium kultury”. Pedagodzy porównawczy wyszukają tu ciekawe analizy odnośnie Japonii - relacji między szkolnictwem a specyfiką uprawiania tego sportu, zaś socjolodzy i antropolodzy kultury znajdą odniesienia do kulturowych praktyk esencjalnie zorientowanych na konsumeryzm, popkulturę, czy polityczną rywalizację $\mathrm{w}$ relacji ze światem, a nawet militaryzm. Idea totalnego futbolu może być kodem kulturowego pokrewieństwa z totalną opozycją w polityce. Książkę kończy niezwykle trafna konstatacja Autora:

(...) o ile inne globalne praktyki kulturowe - takie jak muzyka, moda czy popularny film lub popularne czasopisma - zdają się być w coraz większym stopniu rozpraszane w tysiącach sprzecznych ze sobą swoich własnych wersji i kalek, to piłka nożna trwa w swojej integracji, w swoim wariancie niemalże klasycznym. Jest skonsolidowana wokół swoich reguł i rozgrywek oraz przekazywanych z pokolenia na pokolenie indywidualnych, rodzinnych i kolektywnych identyfikacji. I to także jest źródłem jej władzy we współczesnym globalnym świecie ${ }^{8}$.

Zachęcam zatem do rozbudzania emocji związanych z piłką nożną w kolejnej części artykułu, w której zamierzam pokazać możliwości wykorzystania Mistrzostw Europy w piłce nożnej, które odbywały się pięć lat temu w Polsce i na Ukrainie do metaforycznej analizy nauki, środowiska akademickiego, czy polityki oświatowej w tym okresie.

\footnotetext{
${ }^{7}$ Tamże, s. 66.

${ }^{8}$ Tamże, s. 179.
} 


\section{Zalety mistrzostw dla edukacji językowej}

Można przypuszczać, że Mistrzostwa Europy w piłce nożnej w 2012 roku rozbudzą pasje do uczenia się języków obcych. Do Polski docierały najlepsze drużyny piłkarskie naszego kontynentu. Pobyt zagranicznych gości w naszym kraju mógł rozbudzić silną motywację wewnętrzną u dzieci i młodzieży do uczenia się języków obcych. Mieli szansę spotkać znakomitych piłkarzy Europy, a być może nawet poprosić ich o autograf, zapytać o coś, czy w ramach wolontariatu opiekować się określoną ekipą i gośćmi zagranicznymi. To był znakomity okres do zainteresowania pedagogów publikacjami z glottodydaktyki, którzy nauczają dzieci i młodzież obcych języków ${ }^{9}$. W pięć lat później mogę stwierdzić na podstawie wyników egzaminu maturalnego, że nasza młodzież najlepiej ze wszystkich przedmiotów maturalnych zdała właśnie język angielski. W świetle danych Centralnej Komisji Egzaminacyjnej, średnia wyników matury 2017 na poziomie podstawowym wyniosła z języka angielskiego $71 \%$, a na poziomie rozszerzonym - 60\%, podczas gdy z języka polskiego wynik na poziomie podstawowym stanowił $56 \%$, zaś na poziomie rozszerzonym $-50 \%{ }^{10}$.

Dysponujemy w kraju rozprawami z dydaktyki szczegółowej, których autorzy odwołują się do najnowszych teorii psychodydaktycznych, jak i dziedzin współczesnej wiedzy, będącej przedmiotem powszechnego kształcenia na wszystkich szczeblach polskiej edukacji. Glottodydaktycy przyczynili się do godnego uwagi i szerokiego upowszechnienia w środowisku oświatowym - szkolnym i pozaszkolnym oraz akademickim kształcenia konstruktywistycznego, innowacyjnego i partycypacyjnego, które odchodzi od kształcenia adaptacyjnego, sprzyjając większej efektywności w realizacji zakładanych przez nauczycieli lub uczących się (studiujących) celów. Autorzy piszą swoje rozprawy pod ciśnieniem praktyki, co w dydaktyce języków obcych jest niesłychanie ważne i cenne, skupiając się na przedstawieniu innych warunków pracy nauczycieli z uczącymi się o różnych przecież poziomach motywacji i zdolnościach. Wprowadzane przez nich nowe podejścia teoretyczne i metodyczne w glottodydaktyce współczesnej są doskonałym wypełnieniem pola nieobecności w naszym kraju wielu zagranicznych teorii i modeli, a tym

\footnotetext{
${ }^{9}$ Zob. G. Erenc-Grygoruk, Nauczanie języków obcych w edukacji wczesnoszkolnej, Kraków 2013; D. Gołębniak, G. Teusz, Edukacja poprzez język, Warszawa 1996; E. Jastrzębska, Strategie psychodydaktyki twórczości w kształceniu językowym (na przykładzie języka francuskiego), Kraków 2012; H. Komorowska, Metodyka nauczania języków obcych w Polsce (1957-2007), Warszawa 2007; W. Pfeiffer, Nauka języków obcych. Od praktyki do praktyki, Poznań 2001; A. Szplit, Efektywnie i atrakcyjnie, czyli o przedszkolnym i wczesnoszkolnym nauczaniu języka angielskiego, Kielce 2016; tenże, Bariery psychiczne uczniów w procesie uczenia się języka angielskiego. Diagnozowanie i pokonywanie, Kielce 2017.

${ }^{10}$ Wyniki egzaminu maturalnego 2017 https://www.cke.edu.pl/egzamin-maturalny/egzamin-w-nowej-formule/wyniki/ [odczyt: 2.07.2017].
} 
samym braku zastosowania ich tak w kształceniu, jak i w badaniach. Autorzy czynią je przejrzystymi, proponując własne schematy, czy skupiając się w analizach porównawczych na konstruowaniu tabel.

\section{Niemcy roznieśli Greków, a obywatele roznoszą autorów podręczników oraz politykę MEN}

W czerwcu 2012 roku, kiedy zbliżał się mecz finałowy Niemcy-Grecja ukazał się zbiór ćwiczeń dla uczniów edukacji wczesnoszkolnej, kształcenia zintegrowanego pt. „Ja i moja szkoła”, który zawierał liczne błędy. Rodzice postanowili przerwać milczenie i walczyć z nieprzemyślaną strukturą oraz treścią niektórych zadań. To oni bowiem muszą reagować na dziecięcą bezradność w sytuacji, kiedy ich zdaniem niektóre zadania rozmijają się z sensem i logiką. Co ma zrobić rodzic, kiedy dziecko pyta je: Mamo, co znaczy To mata Toma? Jak stwierdził w korespondencji ze mną jeden $\mathrm{z}$ refleksyjnych rodziców, a zapewne edukowany w swoim dzieciństwie na zupełnie innym zestawie podręczników i zeszytów ćwiczeń: Sa jeszcze ciekawe imiona w niektórych ćwiczeniach np. Otto, Momo, Atma. To jest dopiero edukacja kreatywna. Niech dzieci ucza się w tym kraju międzykulturowego podejścia. Może wkrótce przyjdzie do ich klasy dziecko o imieniu - Momo, albo Atma, czy Otto. Takie imiona poznaje uczeń w pierwszym semestrze I klasy. A może to biuro podróży się reklamuje?

To w okresie poprzedzającym Mistrzostwa Europy powstała w Polsce oddolnie, w opozycji do MEN, 19 maja 2012 roku Obywatelska Komisja Edukacji Narodowej, która zamierzała utworzyć zaplecze eksperckie do wspomagania nauczycieli i rodziców pragnących „przywrócić polskiej szkole jej cele zgodne z polską racją stanu". Komisję utworzyły środowiska protestujące przeciwko reformie programowej kształcenia ogólnego w szkołach ponadgimnazjalnych. Historyk Jan Żaryn przedstawił program dziania tej komisji, który przewidywał m.in. rozwijanie

(...) ruchu protestu przeciwko katastrofalnym zmianom w polskiej oświacie, kreującym szkołę o coraz niższych wymaganiach, której absolwenci prezentują coraz niższy poziom rzeczywistego wykształcenia, przeciwko zmianom prowadzącym $\mathrm{w}$ istocie do zanegowania polskiej tradycji edukacyjnej i demokratycznej ${ }^{11}$.

Zaapelowano w maju 2012 roku do rodziców, nauczycieli i wszystkich osób dobrej woli, by powoływali do życia w lokalnych społecznościach, przy

${ }^{11}$ Eksperci będą wspomagać nauczycieli i rodziców w: http://www.portalsamorzadowy. pl/edukacja/eksperci-beda-wspomagac-nauczycieli-i-rodzicow,34254_2.html 
szkołach publicznych i niepublicznych, szkołach wyższych, parafiach, w lokalnych środowiskach koła Obywatelskiej Komisji Edukacji Narodowej, koła narodowego i obywatelskiego sprzeciwu. Poszukiwano specjalistów w zakresie prawa oświatowego, organizacji i finansowania edukacji, autorów rzetelnych programów kształcenia,

(...) którzy zechcą poświęcić swój czas i wysiłek na działalność pro publico bono tak, aby szkole polskiej przywrócić jej cele zgodne z polską racją stanu - kształcenie i wychowywanie świadomych swych praw obywateli, zakorzenionych w polskiej tradycji, zdolnych przekazywać ją następnym pokoleniom ${ }^{12}$.

To właśnie dzięki temu młodemu ruchowi protestu resort edukacji pod kierownictwem Krystyny Szumilas z PO obiecał, że moduł edukacji w ramach historii w liceach pt. „Ojczysty panteon i ojczyste spory” będzie w minimalnym wymiarze godzinowym obowiązkowy. Eksperci OKEN nie zgodzili się także na redukcję zajęć w liceach z fizyki, chemii, biologii oraz informatyki. Jak stwierdzono w czasie konferencji prasowej OKEN: $W$ istocie rezultatem reformy jest fakt, że dwie ostatnie klasy liceum stracity charakter ksztatcenia ogólnego, co jest ruina idei nauczania licealnego. W wieku 16 lat uczeń musi dokonać wyboru specjalizacji na cate życie. To wbrew logice wspótczesnego, szybko zmieniajacego się świata - wiadomo, że dla młodych ludzi najważniejsza jest obecnie elastyczność, możliwość dopasowania się, ewentualnej zmiany kwalifikacji, do czego przydaje się rozległa wiedza ogólna. Tymczasem, obecna reforma jest przysłowiowym przywiazywaniem szewca do kopyta, ograniczaniem młodemu człowiekowi możliwości wyboru w przyszłości, wpychaniem go w specjalizację w wieku, gdy jest on jeszcze za młody na dokonywanie takiego wyboru. Szkoła nie powinna przygotowywać do sprawnego rozwiazywania testów, tylko do rozwiazywania problemów, jakie niesie życie ${ }^{13}$.

\section{Kto w edukacji nie gra fair play?}

Pierwszy mecz w trakcie Euro 2012 w Warszawie potwierdził, że zawodnicy obu drużyn - Polski i Grecji nie grali fair. Dwie czerwone kartki w inauguracyjnym meczu nie najlepiej świadczyły o przygotowaniu do realizacji założonych celów taktycznych i odporności piłkarzy na prowokacje. Nie byliśmy jednak tak znakomici, jak to nam sugerowano od miesięcy, ale mimo wszystko kibicowałem naszej reprezentacji, życząc jej pozytywnego wyjścia $\mathrm{z}$ tej trudnej sytuacji. Rosjanie w meczu z Czechami pokazali, że wcale nie są tak słabi, jak próbowano ich u nas „malować”. Z grupy jednak nie wyszliśmy. Wstyd. Rozczarowanie. W polskiej edukacji jest wiele podmiotów, które na-

\footnotetext{
${ }^{12}$ Tamże.

${ }^{13}$ Tamże.
} 
ruszają zasady przyzwoitości. Jednym z podmiotów naruszania zasady fair play w edukacji są niektórzy wydawcy podręczników szkolnych. To jednak resort edukacji zaczął w tym okresie promować w dość zaskakujący sposób praktyki nie fair.

Krajowa prasa wówczas donosiła:

MEN wraz z wejściem w życie reformy szkolnej, podpisanej przez Panią minister Katarzynę Hall, wiedząc o monopolistycznej pozycji jednego z wydawców nie poinformowała o tym fakcie Urzędu Ochrony Konkurencji i Konsumenta? Pierwsze kłody pod nogi małych wydawców rzuciło MEN. Podręczniki do recenzji zaczęło Ministerstwo przyjmować od 25 stycznia 2009 roku. Jednocześnie polecono nauczycielom i dyrektorom szkół wybranie podręczników dla uczniów (tylko z listy MEN-u) do 15 czerwca 2009 roku. Wybór książek po tym terminie Ministerstwo uważało za niezgodny z prawem. Te szalone terminy (cztery i pół miesiąca na napisanie, zrecenzowanie, wydrukowanie, rozreklamowanie) mogły być dotrzymane jedynie przez tych wydawców, którzy albo mieli podręczniki już napisane, albo stare starali się zarejestrować jako nowe. Kilkunastu wydawcom udało się zmieścić w terminie. Dokładna analiza tempa rejestracji podręczników wskazuje na to, że jeden z wydawców był łaskawiej traktowany przez recenzentów i pracowników Ministerstwa niż inne wydawnictwa. Może nawet wiedział wcześniej o mających wejść w życie nowych zasadach? $(\ldots)^{14}$

Kiedy rozpoczynały się Mistrzostwa Europy w piłce nożnej w 2012 roku, jednych naukowców one cieszyły, fascynowały, jak np. filozofa prof. Janusza Lipca ${ }^{15}$, innych denerwowały lub były im obojętne, czego przykładem była wypowiedź psychologa społecznego prof. Janusza Czapińskiego ${ }^{16}$. Istniał zatem dualizm akademickich postaw wobec „święta” jednej z dyscyplin sportowych na naszym kontynencie. Dla pedagogów była to doskonała okazja do zaznaczenia roli kultury fizycznej w socjalizacji dzieci i młodzieży, ale także kondycji fizycznej osób dorosłych i starszych. Stefan Wołoszyn tak pisał przed laty o walorach pedagogiki sportu:

My, stare pokolenie, wychowywaliśmy się w klimacie humanizmu sportu, w wierze w czystość moralną naczelnej zasady sportu - zasady „fair play”. Wychowaliśmy się w przekonaniu, że sport jest nie do pomyślenia poza humanizmem i nieskazitelnością etyczną, że sport jest tym nieodłącznym czynnikiem kultury humanistycznej, który posiada wartość perfekcjonistyczną sam w sobie i sam dla siebie, czyli że posiada sam przez się najwyższy walor wychowawczy. Kto uprawia bowiem sport jako wartość

${ }^{14} \mathrm{http}: / /$ www.ksiazka.net.pl/index.php?id=28\&tx_ttnews $\% 5 b t t \_n e w s \% 5 d=12708$

${ }^{15}$ Prof. J. Lipiec, Sport stat się doskonatym substytutem tradycyjnej zabawy ludzkości, czyli gromadnego zabijania się na wojnach, w: http://www.pomorska.pl/artykul/7104131,prof-jozef-lipiec-sport-stal-sie-doskonalym-substytutem-tradycyjnej-zabawy-ludzkosci-czyli-gromadnego-zabijania-sie-na-wojnach,id,t.html [odczyt: 27.06.2017].

${ }^{16}$ Prof. J. Czapiński, Mam w nosie to Euro, w: http:/ / wyborcza.pl/1,76842,11877462,Prof_ Czapinski_Mam_w_nosie_to_Euro_.html\#ixzz1x7KJRdxj [odczyt: 27.06.2017]. 
autoteliczną, podejmuje tym samym najwyższy wysiłek samowychowawczy: przezwyciężania siebie, swoich słabości, dochodzenia w podjętym trudzie do perfekcji ${ }^{17}$.

Powyższe Mistrzostwa otwierał mecz Polska-Grecja, a więc miała miejsce rywalizacja z zawodnikami kraju, który jest kolebką jońskiego ideału kalokagathii Aten. To właśnie w starożytnej Grecji miał miejsce rozkwit i pielęgnowanie wszechstronnego rozwoju osobowości każdego wolnego obywatela, które przetrwały po dzień dzisiejszy jako model integralnego wychowania ciała i duszy. Stadiony Polski i Ukrainy zamieniły się na trzy tygodnie w „świątynie" sportu, przestrzenie wielkich emocji i przeżyć tak zawodników, jak i ich kibiców oraz dbających o oprawę czy bezpieczeństwo różnych służb publicznych i społecznych. Wśród wolontariuszy byli też nasi uczniowie i studenci pedagogiki. Ci ostatni zapewne mieli problem z przygotowywaniem się do egzaminów, toteż być może liczyli na zmęczenie także ich wykładowców egzaminatorów.

Mistrzostwa w piłce nożnej były też wyjątkową okazją do obserwowania postaw zawodników i ich trenerów oraz towarzyszących im służb pod kątem, czy w swoich dążeniach do zwycięstwa przestrzegają sportowej zasady fair play. Rychło okazało się, że ta zasada miała też obowiązywać i być szczególnie premiowana $w$ seksualnych zachowaniach ryzykownych kibiców i przybyłych na Euro 2012 gości, bowiem 22 maja 2012 roku ruszyła kampania "FAIR PLAY. Gram fair, używam prezerwatyw"18. Tak więc Kościół katolicki wypowiedziami swoich hierarchów (m.in. kardynała Kazimierza Nycza w Warszawie, czy Stanisława Dziwisza w Krakowie) w trakcie Uroczystości Najświętszego Ciała i Krwi Chrystusa upomniał się o tę zasadę w odniesieniu do budowania trwałości więzi rodzinnych, państwo zaś o rozwiązłość, wspomaganą rozdawaniem wśród dziesiątek tysięcy uczestników sportowych wrażeń pakietów informacyjnych wraz z pięcioma prezerwatywami. Ot, jak można zasadę fair play wykorzystywać do różnych celów.

\section{Jedna czerwona kartka i dziesięć żółtych dla wyższych szkół w Łodzi}

Ministerstwo Nauki i Szkolnictwa Wyższego dało w okresie Euro 2012 pierwsze czerwone i żółte kartki niektórym wyższym szkołom prywatnym i publicznym. Było to niewątpliwie ostrzeżenie za działanie nie fair na aka-

\footnotetext{
${ }^{17}$ S. Wołoszyn, Olimpizm a wychowanie. Czy można zaufać humanizmowi sportu? [w:] S. Wołoszyn, Pedagogiczne wędrówki przez wieki i zagadnienia. Studia i szkice, przygot. i oprac. Z. Żukowska, Toruń 1996, s. 223.

${ }^{18}$ Fair Play, http://www.aids.gov.pl/kampanie/2012/ [odczyt: 27.06.2017].
} 
demickim rynku. Czerwoną kartkę otrzymała Wyższa Szkoła Pedagogiczna w Łodzi, która - jak się okazało pięć lat później - została zlikwidowana na skutek braku zainteresowania podejmowaniem w niej studiów przez młodzież ${ }^{19}$. Żółte kartki zostały pokazane aż 10 wyższym szkołom tego miasta, w tym 9 prywatnym. Nie da się rywalizować na akademickim stadionie grając na nim nie fair, gdyż w ten sposób zdradza się własnych zawodników i trenerów. Niestety, sędzia główny na akademickim boisku, jakim była Minister Resortu Szkolnictwa Wyższego Barbara Kudrycka, wprowadziła w ramach reformy zapis, który miał na celu między innymi wytrącenie z gry części klubów, czyli tzw. wyższych szkół prywatnych stosujących nieuprawnione praktyki. Dyrektywa w resorcie szkolnictwa wyższego była bardzo czytelna - najwyższy czas uporządkować akademicki rynek i informować opinię publiczną o stosowaniu fauli lub dopingu przez tych graczy, którzy inaczej interpretują obowiązujące zasady lub nie chcą ich w ogóle przestrzegać.

Resort nauki i szkolnictwa wyższego prowadzi od 2002 roku kontrolę "antydopingową", przeciwdziała „korupcji”, by szkoły, których założyciele czy rektorzy działają wbrew zasadom fair play, nie mogły dalej ubiegać się o prawo do udziału w zawodach. Skutki uruchomienia systemu informacji akademickiej POL-on zaczęły wreszcie być zrozumiałe i czytelne dla opinii społecznej. Gracze, którzy z jakichś powodów nie zamierzali grać fair, po prostu są ujawniani na stronach Ministerstwa Nauki i Szkolnictwa Wyższego. Zwiększyła się też liczba sędziów bocznych, którzy wspomagają sędziego głównego w rozpoznawaniu fauli czy spalonego. Wiele dzienników ogólnopolskich co kilka tygodni informuje o podejrzanej praktyce omijania przez właścicieli niepublicznych, a nawet państwowych wyższych szkół zawodowych obowiązujących standardów, pomimo wielokrotnych ponagleń i przypomnień resortu o konieczności ich przestrzegania, jeśli chce się korzystać z dobrodziejstw publicznej pomocy na stypendia. Niektórzy założyciele i rektorzy wyższych szkół prywatnych być może zaryzykowali i podali do bazy POL-on dane, dzięki którym wykryto fakt niespełniania przez nie minimum kadrowego. $\mathrm{W}$ ten sposób opinia publiczna jest ostrzegana, że jakaś szkoła ma zawieszone przez resort uprawnienia do prowadzenia studiów licencjackich czy także magisterskich na określonym kierunku. A zatem, władzom tej szkoły są wręczane czerwone kartki.

Nie była to zresztą jedyna wyższa szkoła prywatna, która została „przyłapana" na praktykach godzących w społeczność tego środowiska. Podobnie zawieszone w 2012 roku prawa do kształcenia na "pedagogice”, tyle tylko że już na poziomie studiów I stopnia, miały: Wyższa Szkoła Handlowa im. Bo-

${ }^{19}$ B. Śliwerski, Czyżby koniec po WSP ZNP także Wyższej Szkoły Pedagogicznej w Łodzi? w: http:/ / sliwerski-pedagog.blogspot.com/2017/01/czyzby-koniec-po-wsp-znp-takze-wyzszej. html [odczyt: 30.01.2017]. 
lesława Markowskiego w Kielcach, Uczelnia Zawodowa Zagłębia Miedziowego w Lubinie i Wyższa Szkoła Społeczno-Ekonomiczna w Warszawie. Być może, gdyby wszystkie wyższe szkoły prywatne zarejestrowały się w bazie POL-on, to lista mających zawieszone uprawnienia do kształcenia mogłaby być dłuższa. Wielu właścicieli tych „wsp”, zapewne z obawy przed demistyfikacją braków, głównie kadrowych, tego nie uczyniło. Dopóki nie ma kontroli Polskiej Komisji Akredytacyjnej lub kontroli MNiSW mogą kształcić, mówiąc językiem sportowym, na tzw. antydopingu lub dzięki „kupieniu meczu”.

W czasie trwania Euro 2012 resort nauki przedstawił listę szkół wyższych, które nie dopełniły obowiązku zgłoszenia swoich studentów do wspomnianego powyżej nowego systemu informacji akademickiej POL-on. Wynik tej kontroli antydopingowej był szokujący, skoro w samej Łodzi aż 9 wyższych szkół prywatnych i jedna publiczna - Akademia Sztuk Pięknych nie zarejestrowały się w tej bazie. Miało to skutkować pozbawieniem ich studentów od kolejnego roku akademickiego budżetowej dotacji na stypendia. Tłumaczenia założycieli czy rektorów lub ich rzeczników były mało przekonujące. Czyżby usiłowano ominąć rejestrację, by dzięki temu dalej prowadzić rekrutację na studia z ryzykiem pozbawienia jakże koniecznych dla wielu osób stypendiów? Czy może zlekceważono potencjalne, a negatywne skutki braku rejestracji w bazie? Na czarnej liście MNiSW z żółtą kartką znalazły się (szkoły, prowadzące m.in. „pedagogikę" jako kierunek studiów są podkreślone ${ }^{20}$ :

1. Akademia Sztuk Pięknych im. Władysława Strzemińskiego w Łodzi

2. Salezjańska Wyższa Szkoła Ekonomii i Zarządzania w Łodzi

\section{Społeczna Akademia Nauk z siedzibą w Łodzi}

4. Wyższa Szkoła Administracji Publicznej w likwidacji z siedzibą w Łodzi

5. Wyższa Szkoła Edukacji Zdrowotnej i Nauk Społecznych w Łodzi

6. Wyższa Szkoła Informatyki w Lodzi

7. Wyższa Szkoła Marketingu i Biznesu w likwidacji z siedzibą w Łodzi

8. Wyższa Szkoła Sportowa im. Kazimierza Górskiego w Łodzi

9. Wyższa Szkoła Sztuki i Projektowania w Łodzi

10. Wyższa Szkoła Turystyki i Hotelarstwa w Łodzi

Jak stwierdził rzecznik prasowy MNiSW G. Loba: Zdecydowana większość uczelni w sposób płynny dokonata przejścia na nowoczesny elektroniczny system informacji. Na każdym etapie stużymy wsparciem merytorycznym i technicznym. Uczelnie, które jeszcze mimo naszych monitów listownych i telefonicznych nie zrealizowały ustawowego zadania, musza się liczyć z konsekwencjami. Nie chcemy jednak, żeby zaniedbanie uczelni uderzało w studentów. Resort nauki podkreśla, że przesyłat już kilkakrotnie (w grudniu 2011 roku oraz w lutym, marcu, kwietniu i maju 2012

${ }^{20}$ Uczelnie z Łodzi na czarnej liście w: http://www.dzienniklodzki.pl/artykul/597315, uczelnie-z-lodzi-na-czarnej-liscie-ministerstwa,id,t.html) [odczyt: 27.06.2017]. 
roku) monity do spóźnionych uczelni, przypominając, że "nieprzesłanie danych budzi poważne wątpliwości co do spetniania niezbędnych warunków do prowadzenia studiów ${ }^{21}$.

Żółta kartka jest ostrzeżeniem i daniem szansy na poprawę.

\section{Zakończenie o tym, jak zdobyć profesurę pod „zamkniętym dachem futbolowego stadionu"}

W 2011 roku ukazała się książeczka zatytułowana Wspinaczka po profesurę - od upadków na kolana i ciosów w plecy do zaszczytów. Przewodnik satelitarny po karierze akademickiej22, która okazała się tylko pozornie żartobliwym vademecum dla (niekoniecznie) ambitnych naukowców chcących zrobić karierę profesorską. Jej autorem jest profesor zwyczajny matematyki Gianfranco Gambarelli z Uniwersytetu w Bergamo, który pisze wiersze i eseje, a więc człowiek renesansowo podchodzący do swojej profesji. Można zapytać, a po co Polakom włoski przewodnik po świecie nauki, skoro w gorącej Italii nie ma habilitacji? Czego zatem możemy nauczyć się od il professore? Publikację przetłumaczył profesor AGH Zbigniew Łucki, też matematyk, autor między innymi Matematycznych technik zarządzania ${ }^{23}$. Znakomicie, że są profesorowie, którzy potrafią o sprawach poważnych i trudnych mówić językiem łatwym, klarownym i zarazem żartobliwym. Mamy zatem publikację, której treść jest grą słów, skojarzeń, odniesień do realiów akademickich procedur, okraszanych żartem, wierszykami i ciekawymi metaforami. Jak pisze w zakończeniu wierszem G. Gambarelli:

Naprzód

Rosnąć, iść naprzód, piąć się,

przechodzić, wyprzedzać, dryblować

wierzyć, słuchać rozkazów, walczyć,

nie widzę końca: naprzód, naprzód, naprzód;

$(\ldots)^{24}$.

Nie traktowałbym tej popkulturowej książeczki jako poradnika, dzięki któremu rzeczywiście można zrobić karierę, bo wiele jest w niej banałów,

${ }^{21}$ Zaniedbania części uczelni mogą pozbawić studentów stypendiów http:/ / serwisy.gazetaprawna.pl/edukacja/artykuly/624363,zaniedbania-czesci-uczelni-moga-pozbawic-studentow-stypendiow.html [odczyt: 26.06.2017].

${ }_{22}^{2}$ G. Gambarelli, Wspinaczka po profesurę. Przewodnik satelitarny po karierze akademickiej - od upadków na kolana i ciosów w plecy do zaszczytów, przekł. Z. Łucki, Warszawa 2011.

${ }^{23}$ Z. Łucki (red.), Matematyczne techniki zarządzania, Kraków 1998.

${ }^{24}$ G. Gambarelli, Wspinaczka po profesure, s. 129. 
oczywistości, choć i także humoru, ironii i dużego dystansu do niedostępnego dla wielu świata wielkiej nauki. Możemy jednak dzięki temu studium przekonać się, że i na południu Europy wcale nie podchodzi się z taką nabożnością do systemu bolońskiego. Także tam uczy się młodych adeptów tego, jak przechytrzyć proceduralizm, „zabezpieczyć sobie” karierę naukową, by móc po latach jej konsumowania pisać tego typu książeczki. W kraju mamy pełno tego typu poradników na temat tego, jak przeżyć szkołę, jak wychować kota i męża, jak bić dzieci, jak oszukiwać w szkole lub jak przeżyć radę pedagogiczną. Gambarelli pisze o tym, co jest ważne przy doktoracie i dlaczego mimo różnych regulacji ustawowych nie da się zapewnić obiektywności ocen członków komisji. Dowiemy się też, jak utrzymać się przy szefie oraz co zrobić z donosicielstwem i zmową milczenia (nie tylko) w tym środowisku. Jest też rozdział o tym, jak przetrwać studentów, jak poradzić sobie z recenzentami oraz jak przygotować się do wygłoszenia referatu czy obrony pracy naukowej. Organizatorzy konferencji dowiedzą się też, jak poradzić sobie z maruderami czy przedłużającymi swoje wystąpienia. Najzabawniejsza jest na końcu ta część książki, w której autor prezentuje lokalną zoologię akademicką.

Już widzę oczami wyobraźni, kto spośród znanych mi osób mógłby być zaliczony do „szarańczy” lub „fagocytów”, kto byłby „gołębicą”, a kto „wężem". W ogólnej zoologii akademickiej znajdą się też sklasyfikowani akademicy jako "kukułki”, "aniołki”, „bąkojady” i "zajączki”. Niektórzy, choćby nie wiem, jak się starali, biegali po boisku, strzelali w kierunku bramki przeciwnika, faulowali, zabiegali o względy sędziego bocznego czy nawet głównego, to jednak pod zamkniętym dachem pseudoakademickiej szkoły wyższej, z kiepskim trenerem i prezesem small biznesu tylko się spocą, nabiegają, stracą siły, a gola nie zdobędą. Postfutbolowa literatura naukowa i popularnonaukowa może być $\mathrm{w}$ humanistyce inspiracją do konstruowania nowych projektów badawczych, z wykorzystaniem piłki nożnej jako metafory.

\section{BIBLIOGRAFIA}

Czapiński J., Mam w nosie to Euro, w: http:/ / wyborcza.pl/1,76842,11877462,Prof_Czapinski_Mam_w_nosie_to_Euro_.html\#ixzz1x7KJRdxj [odczyt: 27.06.2017].

Czubaj M., Myszkorowski J. i in., Postfutbol. Antropologia piłki nożnej, Wydawnictwo Katedra, Gdańsk 2012.

Erenc-Grygoruk G., Nauczanie języków obcych w edukacji wczesnoszkolnej, Oficyna Wydawnicza Impuls, Kraków 2013.

Fair Play, http://www.aids.gov.pl/kampanie/2012/ [odczyt: 27.06.2017].

Gambarelli G., Wspinaczka po profesurę. Przewodnik satelitarny po karierze akademickiej od upadków na kolana i ciosów w plecy do zaszczytów, przekł. Z. Łucki, CeDeWu, Warszawa 2011.

Gołębniak D., Teusz G., Edukacja poprzez język, Wydawnictwo CODN, Warszawa 1996. 
http:/ / serwisy.gazetaprawna.pl/edukacja/artykuly/624363,zaniedbania-czesci-uczelni-moga-pozbawic-studentow-stypendiow.html [odczyt: 26.06.2017].

http:/ / www.dzienniklodzki.pl/artykul/597315,uczelnie-z-lodzi-na-czarnej-liscie-ministerstwa,id,t.html) [odczyt: 27.06.2017].

http:/ / www.ksiazka.net.pl/index.php?id=28\&tx_ttnews\%5btt_news\%5d=12708

http://www.portalsamorzadowy.pl/edukacja/eksperci-beda-wspomagac-nauczycieli-i-rodzicow,34254_2.html

https://www.cke.edu.pl/egzamin-maturalny/egzamin-w-nowej-formule/wyniki/ [odczyt: 2.07.2017].

Jastrzębska E., Strategie psychodydaktyki twórczości w kształceniu językowym (na przykładzie języka francuskiego), Oficyna Wydawnicza Impuls, Kraków 2012.

Komorowska H., Metodyka nauczania języków obcych w Polsce (1957-2007), Wydawnictwo CODN, Warszawa 2007.

Lipiec J., Sport stał się doskonatym substytutem tradycyjnej zabawy ludzkości, czyli gromadnego zabijania się na wojnach w: http://www.pomorska.pl/artykul/7104131,prof-jozef-lipiec-sport-stal-sie-doskonalym-substytutem-tradycyjnej-zabawy-ludzkosci-czyli-gromadnego-zabijania-sie-na-wojnach,id,t.html [odczyt: 27.06.2017].

Łucki Z. (red.), Matematyczne techniki zarzadzania, Wydawnictwo AGH, Kraków 1998.

Melosik Z., Tożsamość, ciało i władza w kulturze instant, Oficyna Wydawnicza Impuls, Kraków 2010.

Melosik Z., Piłka nożna. Tożsamość, kultura i władza, Wydawnictwo Naukowe UAM, Poznań 2017.

Pfeiffer W., Nauka języków obcych. Od praktyki do praktyki, Wydawnictwo WAGROS, Poznań 2001.

Szplit A., Efektywnie i atrakcyjnie, czyli o przedszkolnym $i$ wczesnoszkolnym nauczaniu języka angielskiego, Wydawnictwo Pedagogiczne ZNP, Kielce 2016.

Szplit A., Bariery psychiczne uczniów w procesie uczenia się języka angielskiego. Diagnozowanie i pokonywanie, Wydawnictwo UJK, Kielce 2017.

Śliwerski B., Czyżby koniec po WSP ZNP także Wyższej Szkoły Pedagogicznej w Łodzi? w:http://sliwerski-pedagog.blogspot.com/2017/01/czyzby-koniec-po-wsp-znp-takze-wyzszej.html [odczyt: 30.01.2017].

Wołoszyn S., Olimpizm a wychowanie. Czy można zaufać humanizmowi sportu? [w:] S. Wołoszyn, Pedagogiczne wędrówki przez wieki i zagadnienia. Studia i szkice, przygot. i oprac. Z. Żukowska, Wydawnictwo Adam Marszałek, Toruń 1996. 